\title{
COMPARTILHANDO EXPERIÊNCIAS E "IMPREVISTOS": RELATOS E REFLEXÕES SOBRE A PRÁTICA DA FILMAGEM EM PESQUISAS ANTROPOLÓGICAS
}

\author{
Regina Abreu ${ }^{12}$
}

\section{Apresentação}

Instigada pela proposta da Revista Iluminuras, apresento aqui alguns relatos de experiências ocorridas em minha prática como antropóloga com relação ao uso do audiovisual. A marca central destes relatos incide sobre uma certa esfera do imprevisível desencadeado pelo registro audiovisual e, em particular, pelo agenciamento da câmera, junto a diferentes grupos sociais. Elas evidenciam um conjunto diversificado de representações sobre a prática da filmagem e a edição de filmes. Seguindo a linha proposta por Jean Rouch, e retomada por Rafael Devos, busco refletir sobre diferentes possibilidades e consequências que podem advir quando se coloca uma câmera em movimento, ou seja, quando uma câmera se torna "personagem" em situações muito específicas da vida social. ${ }^{3}$ Procuro mostrar como as tensões são muito diversificadas e dizem respeito às percepções sobre o poder e o alcance de uma filmagem. Primeiro, no ato performático mesmo da filmagem que envolve um conjunto de interlocutores em arenas públicas ou privadas. Segundo, no ato do imaginário sobre o filme propriamente dito, o produto que resultará dali. Terceiro, sobre o ato da difusão, do alcance, da circulação do filme e de suas consequências. Sabemos que um filme implica numa construção de linguagem num contexto comunicacional complexo, com um antes e um após as filmagens. Mas, o momento da filmagem é um momento crucial onde se cruzam, de um lado, pesquisadores, cinegrafistas e produtores e, de outro lado, aqueles que são filmados em seus territórios, com seus objetos, nos mais diferentes contextos. Neste momento, muita coisa pode acontecer, e de fato acontece, expondo as subjetividades, as fragilidades e, muitas vezes, expressando nossos equívocos sobre o que pensávamos sobre os "outros". Momento que pode ser de êxtase ou de frustração.

\footnotetext{
${ }^{1}$ Universidade Federal do Estado do Rio de Janeiro, Brasil.

${ }^{2}$ Regina Abreu é antropóloga, professora e pesquisadora do Programa de Pós-Graduação em Memória Social da UNIRIO. Coordena o Grupo de Pesquisa "Memória, Cultura e Patrimônio" com apoio do CNPq, Capes, Faperj. É autora de livros e ensaios e realizadora de filmes sobre o tema da Memória Social, do Patrimônio e dos Museus. E-mail: abreuregin@gmail.com.

${ }^{3}$ Devos, Rafael. "Quando a câmera "vira personagem": ponto de vista em movimentos na busca de imagens do outro em documentários etnográficos". In: Revista Iluminuras, v. 2, n. 3 (2001), UFRGS. Disponível em: http://seer.ufrgs.br/iluminuras/issue/view/768.
} 
Mas, que pode trazer o novo, o impensado, aquilo que não tínhamos previsto e que nossa metodologia, nossos roteiros, nossas tecnologias muitas vezes não dão conta. É sobre estes "imprevistos" carregados de significações que falarei aqui. "Imprevistos" que denotam que as percepções que vamos construindo durante um processo de pesquisa podem se modificar completamente, podem ser canibalizadas por um "nativo" que se recusa a ficar no lugar do entrevistado e não responde suas perguntas, mas afirma seu direito de falar aquilo que ele quer falar para a "câmera", esta caixa mágica que se imagina fazerem ressoar as vozes e as imagens pelo mundo afora. "Imprevistos" que podem de uma hora para outra mudar a rota de um filme quando, por questões éticas, decidimos não difundir imagens cuidadosamente registradas ou depoimentos importantíssimos, para proteger uma população do crivo da polícia e da ação penal. "Imprevistos" que podem potencializar ações políticas importantes desencadeadas por nosso encontro com os "outros". "Imprevistos" que inesperadamente precipitam o fim de alguns projetos que gostaríamos que fossem à frente.

Gostaria também de chamar a atenção que na minha prática profissional, estive sempre trabalhando em equipes interdisciplinares, o que coloca o registro etnográfico e, em particular o uso do audiovisual, num lugar de permanente debate e onde se fazer entender vem implicando um exercício de escuta e tolerância. Em muitas ocasiões, aproveitei oportunidades de pesquisa para filmar e introduzir em equipes muito diversificadas um pouco da metodologia e das inquietações antropológicas. Nem sempre os registros audiovisuais na pesquisa antropológica seguem os percursos clássicos de eleição do tema, mapeamento bibliográfico, leituras e discussão teórica, construção do objeto, delimitação do campo, obtenção de financiamento, organização da equipe e dos equipamentos, elaboração de roteiro, construção da metodologia, ida a campo, filmagem, edição, difusão. Muitas vezes, surgem oportunidades únicas, "imperdíveis", e partimos para o campo ainda com muitas questões e dúvidas. Outras vezes, pelo contrário, temos muitas leituras e reflexões sobre o tema a priori e nos surpreendemos com o campo que nos inquire, nos tira de nosso lugar, nos coloca outros desafios. Aprender a agir nestas situações "imprevisíveis" e tirar lições destas experiências é tão importante quanto o arsenal de teorias, métodos e técnicas que adquirimos na Universidade, descobrimos que nunca estamos totalmente preparados e, no fundo, somos a cada novo processo, uma vez mais, iniciantes. Não só porque trabalhar com o registro audiovisual na pesquisa antropológica é sempre uma aventura, mas também porque implica lidar com as inter-subjetividades. Em meus registros 
audiovisuais, geralmente tenho estado acompanhada de pelo menos um cinegrafista e assistentes. Já manipulei a câmera e filmei muitas vezes, mas na maior parte das minhas pesquisas, tenho trabalhado com profissionais ou com alunos. Em outras ocasiões, tenho trabalhado em equipes mais amplas relacionadas a projetos com um ou mais objetivos, onde o meu projeto é apenas mais um. Portanto, são muitas perspectivas, muitos encontros e também desencontros. Mas, que enriquecem as experiências e os processos de pesquisa. Trabalhar com o audiovisual é para mim uma premissa. Quando penso em pesquisa, penso sempre no registro audiovisual. Não faço entrevista, não registro, não ando sem uma câmera.

Além da equipe interdisciplinar, estive sempre envolvida em situações onde os interlocutores, ou seja, o grupo pesquisado primava pela heterogeneidade de interesses e pontos de vista, o que tornavam ainda mais complexas estas experiências. É pois sobre estas duplas e complexas relações, onde de um lado, o pesquisador está longe de ser o indivíduo isolado na solidão da aldeia e, de outro lado, o "nativo" está longe de ser um único representante de sua espécie, que eu gostaria de falar. Minha reflexão vai pois nesta via de mão dupla constituída por uma pesquisa antropológica que se tece em contextos interdisciplinares e se coloca diante de uma multiplicidade de agentes.

A condição prévia da interdisciplinaridade no processo de produção das pesquisas, e principalmente dos filmes envolvidos em minhas experiências, bem como a relação com a multiplicidade de agentes com que venho dialogando durante a realização dos registros audiovisuais têm colocado também uma outra questão: como ouvir as múltiplas vozes que nos atravessam e atravessam nossos interlocutores? Como realizar um produto final, editar um filme que dê conta destes múltiplos atravessamentos? ${ }^{4}$

Muitos autores têm enfatizado o importante papel da linguagem no contexto comunicacional em que existimos. Somos o que falamos e como falamos. Realizar um projeto de pesquisa com a prática do audiovisual significa entrar em comunicação permanente com a equipe com a qual trabalhamos e com aqueles que entrevistamos, registramos e cuja vida social desejamos compreender ou interpretar. Por outro lado, a comunicação é sempre uma via de mão dupla, onde somos também identificados, decodificados e, de certo modo, entrevistados. A comunicação que se estabelece no ato da pesquisa e do registro audiovisual envolve muitos mundos, muitas subjetividades,

\footnotetext{
${ }^{4} \mathrm{O}$ conceito de "atravessamento" em Deleuze expressa a ideia de forças deflagradoras, o conjunto de vetores que produz múltiplas dimensões nos sujeitos. Ver: DELEUZE, Gilles. "Sobre Spinoza". In: Cours Vincennes, 1978. em: http://www.webdeleuze.com/php/texte.php?cle=194\&groupe=Spinoza\&langue=5.
} 
muitas representações. Embora procuremos a todo instante, manter o controle sobre as situações, estabelecendo um acordo entre as partes segundo a ética da pesquisa ${ }^{5}$, metas definidas, delimitação do campo, estabelecimento de metodologia, roteiro de filmagens e de entrevistas, ocorrem muitas vezes "imprevistos". Estes "imprevistos" não devem ser vistos como negativos. Pelo contrário, eles são altamente expressivos. Eles falam sobre as pessoas, as convicções, as crenças, os valores, os propósitos. Falam também de como as pessoas nos vêem, de como nos representam. E, no caso do registro audiovisual, falam de como representam este "personagem" que é uma câmera, com seu poder e também com sua magia. Coloque-se na frente de uma câmera, procure falar para ela. O que você vai dizer? Como vai se sentir? O que você vai pensar sobre as pessoas que estão entrevistando e filmando você? Que fantasias você fará a respeito do uso destas imagens? Que referências você tem sobre o registro audiovisual? Quais as suas expectativas com relação a um registro audiovisual sobre sua vida, sua casa, o ritual de que você participa, a cidade onde você mora? E, principalmente, quais os temores que você têm sobre os usos da sua imagem, as edições que podem ser feitas com a sua imagem, as associações que podem advir? Sua imagem, sua fala serão coladas a que outras imagens? Quem irá editá-las? Quais os jogos de poder e de verdade estão por trás dos filmes e dos registros audiovisuais? Quais as formações discursivas que nos habitam e que emergem nas construções dos filmes em todas as suas etapas? $\mathrm{O}$ que significa dizer para uma câmera? O que significa dizer com uma câmera? O que significa dizer a partir do que foi captado por uma câmera? ${ }^{6}$

É preciso ter claro desde o início que a aventura da filmagem e da construção de um filme implica em jogos de linguagem e expressões discursivas que vão se justapondo, se contrapondo ou se compondo durante o trabalho com o audiovisual. A premissa da qual partimos é de que o ato da filmagem e as construções discursivas que implicam o fazer filmes não são atos corriqueiros, naturais e desprovidos de

\footnotetext{
${ }^{5}$ Ver no Portal da Associação Brasileira de Antropologia, o código do antropólogo e da antropóloga: http://www.abant.org.br/?code=3.1.

${ }^{6}$ Diferentes autores focalizaram o tema das construções discursivas e das relações entre linguagem e poder, entre eles destaco: FOUCAULT, Michel (1992). O que é um autor? Lisboa: Vega; FOUCAULT, Michel (1997). A ordem do discurso. Lisboa: Relógio d’Água. BARTHES, Roland (2004b) O grau zero da escrita. São Paulo: Martins Fontes. BENJAMIN, Walter (1992). Sobre arte, técnica, linguagem e política. Lisboa: Relógio d'Água. CERTEAU, Michel de (2007). A escrita da História. Rio de Janeiro: Forense Universitária.
} 
complexidade. Como assinalaram Cornelia Eckert e Ana Luisa Carvalho da Rocha ${ }^{7}$, a partir das observações de Walter Benjamin,

(...) as novas tecnologias (inauguradas com o cinematógrafo e a sofisticação dos experimentos com a técnica da fotografia no século $\mathrm{XX}$ ) trariam modificações profundas no aparato perceptivo do homem urbano-moderno. A técnica do registro visual, desde aí, revela ao homem moderno sua capacidade de desvendar mundos sensíveis que não eram antes percebidos: a poética nas formas interativas ordinárias e cotidianas, por exemplo, o conhecimento e a precisão dos fatos observados pela ciência (...)

(Rocha e Eckert, 2001: 2)

A técnica do registro audiovisual carrega consigo sua marca fundacional. Produto do capitalismo industrial num contexto de hegemonia da noção de progresso com o incentivo claro à inventividade e da busca da criação mesclada ao crivo da racionalidade positivista, a câmera surge assim como o grande invento que permite concomitantemente "documentar" as "realidades" e ficcioná-las. Instrumento de construção de verdades e de criação de estórias e mundos de fantasia, o cinema tem desde o início esta característica dúbia de fabricação de informações e de deformações ou ficções. Este duplo imaginário perpassará as representações discursivas sobre a atividade fílmica durante o século XX. Cinema-documentário e cinema-ficção emergem como duas áreas conexas e, ao mesmo tempo, radicalmente diferenciadas. A ideia, de prova, testemunho, documento, tão cara à ciência positivista que se instala no final do século XIX e início do século XX procura aliciar o grande invento para seus propósitos na busca de verdades inquestionáveis. Foi somente na segunda metade do século XX, com o grande debate sobre as formações discursivas do Ocidente Moderno e a relação entre linguagem e poder, com autores como Michel Foucault, Roland Barthes e, no campo da História, Jacques Le Goff e Michel de Certeau, que tornou-se possível perceber e aprofundar os limites de produção de verdade do positivismo no campo do discurso.

E é neste contexto que abriu-se caminho para refletir e levantar questões sobre as narrativas fílmicas como produções de verdades positivas. Eckert e Rocha chamam a atenção de que "lembrar o ilusionismo e os efeitos de simulação técnica da unidade temporal que presidem a arte de narrar, tanto no cinema ficcional quanto no cinema documental, e suas interfaces, para o caso da Antropologia, é não esquecer o

\footnotetext{
${ }^{7}$ ROCHA, Ana Luiza Carvalho da e ECKERT, Cornelia. "Imagem recolocada: pensar a imagem como instrumento de pesquisa e análise do pensamento coletivo". In: Iluminuras, v.2, n.3. Porto Alegre: BIEV/ UFRGS, 2001. p. 2.
} 
comprometimento da produção de filmes etnográficos com o campo da narrativa." Ou seja, ambos os campos, tanto do cinema documental quanto do cinema ficcional utilizam os mesmo recursos ilusionistas, "simulando o tempo num continuum de instantes logicamente hierarquizados, quando, no entanto, sua feição é granular e fragmentária". ${ }^{8}$

A operação de construção do documento "etnográfico" a partir da narrativa fílmica já foi bem explorada na literatura do campo da Antropologia Visual. Esta literatura aponta como o cinema-documentário e, inclusive, o documentário etnográfico, foi eficaz na produção de monumentos, na consagração de pontos de vista ocultos apresentados como "realidades filmadas". Deste perigo de sacralização e de monumentalização da vida social, penso já termos escapado. Hoje, uma das primeiras lições em Antropologia Visual envolve a assertiva de que a narrativa fílmica envolve muitas mediações, pontos de vistas, interlocuções, jogos de poder e linguagem. Assertiva que foi particularmente enfatizada a partir também dos inúmeros questionamentos sobre os textos etnográficos ${ }^{9}$, enfatizando a ideia da experiência etnográfica, da vivência única e singular no campo como fundamental para a construção posterior de uma narrativa não mais como verdade, mas como possibilidade de interpretação para alguns, e como busca de compreensão para outros. ${ }^{10}$

Assim, problematizar os contextos, os processos, as mediações e os "imprevistos" durante as práticas de registros audiovisuais, mais do que um capítulo à parte dos resultados, pode ser, pelo contrário, um atalho para entender a complexidade crescente que envolve do registro audiovisual nas pesquisas antropológicas.

\section{"Santa Maria": a imagem tabu ou o que fazer com o tabu feito imagem}

Minha primeira experiência com o registro audiovisual no contexto de uma pesquisa antropológica se deu ainda nos anos oitenta, mais precisamente em 1984, quando juntamente com o cineasta Noilton Nunes acompanhei a segunda parte de uma expedição à floresta Amazônica para documentar os usos da ayahuasca numa comunidade tradicional formada por uma população cabocla de ex-seringueiros. Com a queda da produção da borracha, este grupo havia passado a viver em uma comunidade

\footnotetext{
${ }^{8}$ Rocha e Eckert, op. cit., 2001, pág. 4.

${ }^{9}$ Ver: CLIFFORD, James. A Experiência Etnográfica. Antropologia e Literatura no século XX. Rio de Janeiro: UFRJ, 1998.

${ }^{10}$ Refiro-me aqui ao interpretativismo e à sociologia compreensiva.
} 
de base religiosa nas cercanias de Rio Branco, no Acre, a "Colônia 5.000". Mais tarde, este mesmo grupo adentrou a floresta ocupando também um antigo Seringal desativado que batizaram de "Seringal Rio do Ouro". A Comunidade conhecida por "Comunidade do Santo Daime" era liderada por um senhor alto, magro, de longas barbas brancas, que todos chamavam de "Padrinho Sebastião". "Padrinho" era a designação que se dava aos líderes da Comunidade e "Madrinha" a designação dada às suas esposas. A Comunidade do Padrinho Sebastião estava despertando a atenção do Governo Federal devido à ampla difusão do uso da ayahuasca na região e também pelo motivo de que esta comunidade vinha atraindo adeptos de outros centros urbanos, inclusive de regiões mais distantes, do sudeste do país.

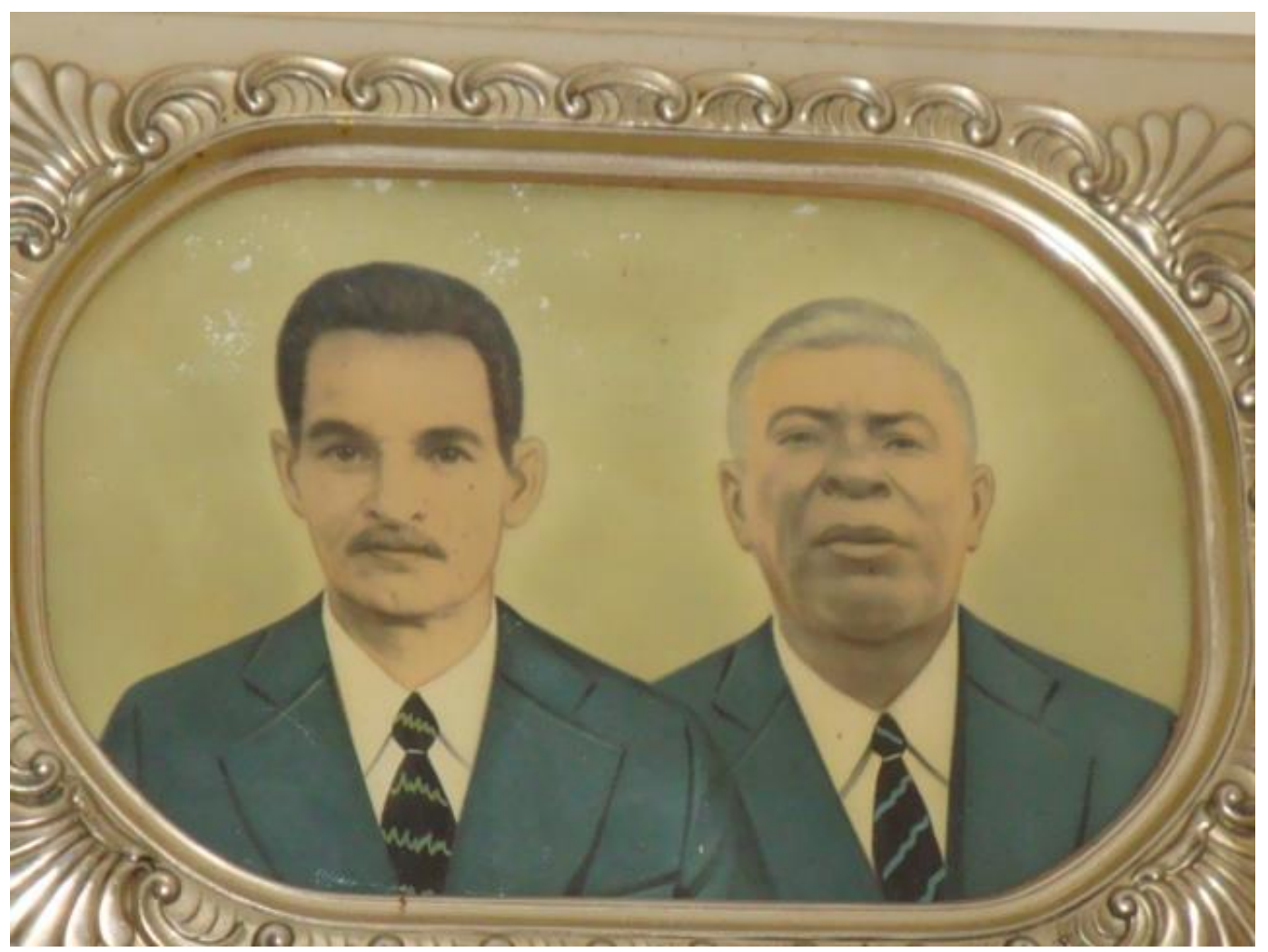

1. Padrinho Sebastião e Mestre Irineu. Foto de Regina Abreu, 1984.

Uma vez que a ayahuasca era uma bebida com componentes considerados alucinógenos, havia uma preocupação do Ministério da Justiça e do Conselho Federal de Entorpecentes com relação ao seu uso cada vez mais expandido. Para conhecer de 
perto o fenômeno, o Ministério da Justiça decidiu organizar e liderar uma expedição à Comunidade do "Padrinho Sebastião".

Participavam da expedição além de membros do Ministério da Justiça e do Exército, uma equipe interdisciplinar formada por uma historiadora, um ou dois psicólogos, um sociólogo, um ou dois antropólogos, educadores, além de simpatizantes do Santo Daime. O documentarista Noilton Nunes acompanhou a mesma, realizando na primeira parte da viagem uma documentação sobre a investigação do Ministério da Justiça e a vida social na Comunidade do Santo Daime. Quando vi o material filmado desta primeira expedição da qual não estive presente, fiquei surpresa. Era a primeira vez que uma câmera de vídeo chegava naquelas localidades, o que havia despertado grande curiosidade dos florestânicos que foram muito receptivos para a filmagem. A partir deste primeiro material, Noilton e eu decidimos empreender nova viagem à Amazônia, já com o intuito de documentar aspectos bem precisos do ritual em torno do Santo Daime: processo de confecção da bebida; musicalidade; princípios religiosos; organização social; rituais. Nesta viagem, pudemos trabalhar com maior distanciamento e profundidade. Percebemos muito claramente que aquele grupo social se estruturava em torno não apenas do uso ritual do santo daime - "ayahuasca" - , mas também do uso ritual da "cannabis sativa" que na comunidade era designada por "santa maria". Este nome havia sido atribuído pelo Padrinho Sebastião a esta planta em alusão a Maria, mãe de Jesus Cristo que, como ele narrava, havia lhe aparecido na floresta e lhe iniciado em seu uso para cura medicinal. Percebemos que a distinção e a relação entre um mundo masculino e um outro feminino eram muito importantes para os adeptos da Comunidade do Santo Daime. Estes eram marcados e simbolizados pelo Santo Daime e pela Santa Maria. A experiência do uso ritual da "Santa Maria" colocava questões difíceis para a Comunidade, pois a "cannabis sativa" encontrava-se na lista de "tóxicos" ou substâncias proscritas pelo Conselho Federal de Entorpecentes - COFEN - em todo o território nacional, sendo seu uso (como ainda é) considerado crime passível de punição por lei. 


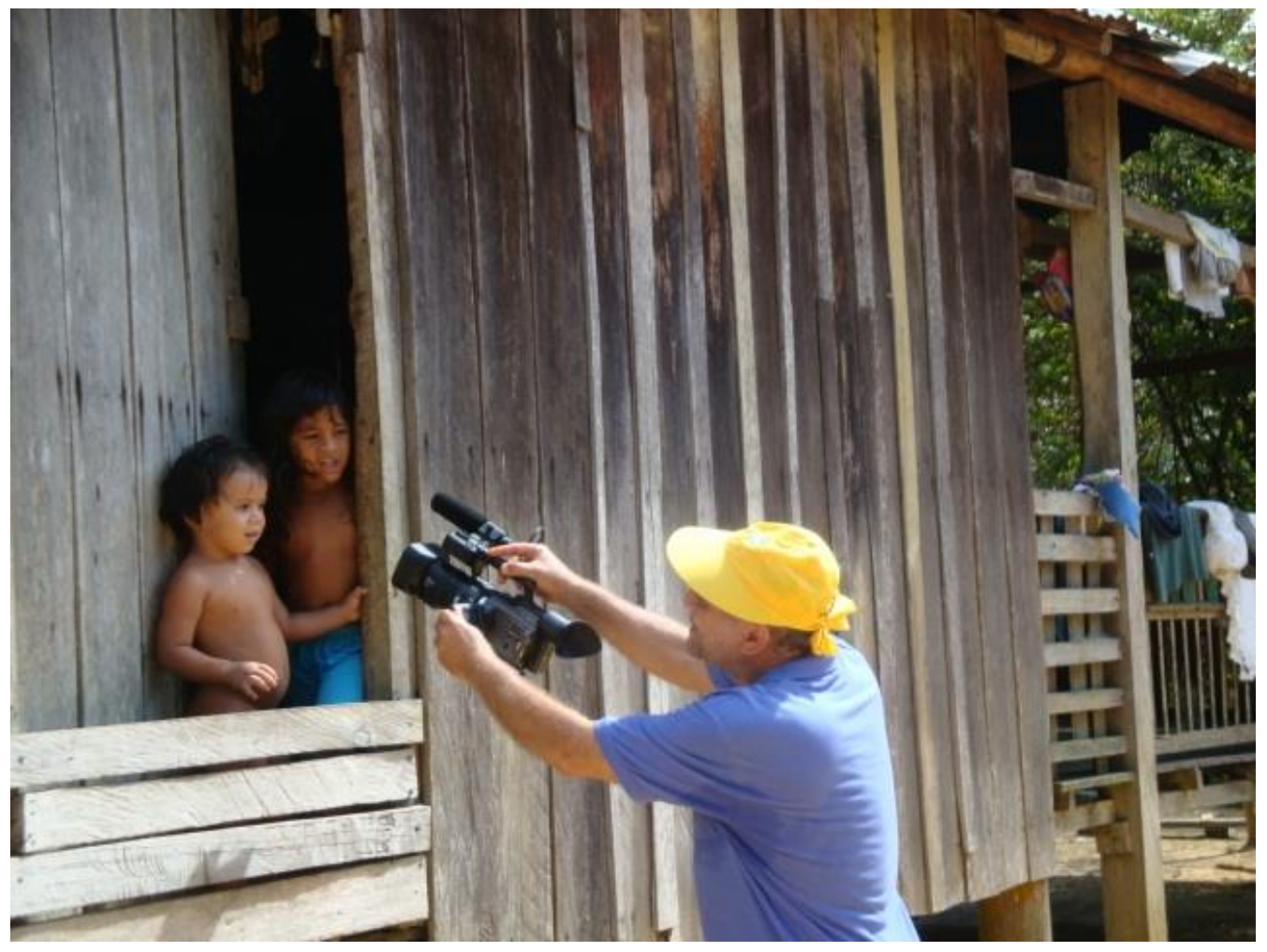

2. Filmagem na comunidade do Santo Daime. Foto de Regina Abreu, 1984.

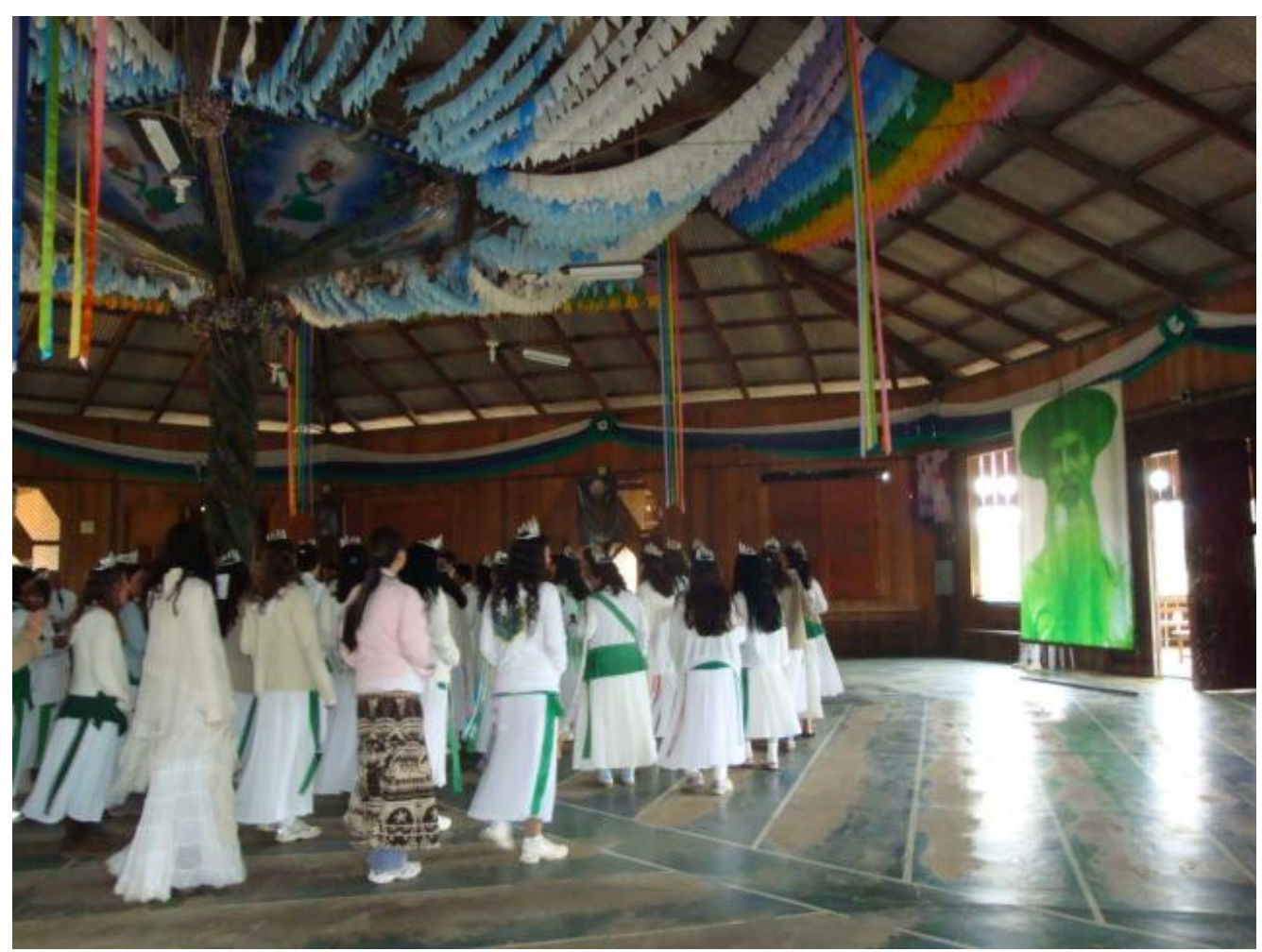

3. Ritual na comunidade do Santo Daime. Foto de Regina Abreu, 1984. 
Ou seja, havia um aspecto tenso e complicado com relação ao uso ritual das substâncias "ayahuasca" e "cannabis sativa" nos rituais da Comunidade do Santo Daime. Se, por um lado, ambas eram estruturantes da cosmologia do grupo, inclusive correspondendo a alegorias de entes sagrados, masculinos e feminos, sincretizados com a figura de Jesus Cristo e da Virgem Maria, por outro lado, para mim como antropóloga, mostrar estas conexões e ainda mais, enunciá-las por meio de imagens onde anciãos e anciãs, homens e mulheres, jovens e crianças apareciam bebendo "ayahuasca" e fumando "cannabis" oferecia um perigo real para o próprio grupo.

Durante a expedição do Ministério da Justiça, alguns dos profissionais envolvidos procuraram em seus relatórios enfatizar as características positivas da vida social na Comunidade do Santo Daime e os sentidos culturais do ritual da "ayahuasca", chamando a atenção para o fato de que esta era uma bebida muito difundida na região, produto de plantas endêmicas da Amazônia. Ou seja, havia um esforço na direção de evitar que a "ayahuasca" pudesse ser proscrita pelo Conselho Federal de Entorpecentes e viesse a ser associada com a criminalização.

A descoberta do uso da "cannabis sativa" como um elemento importante e decisivo para a Comunidade do Santo Daime era explosivo. Muitos dos profissionais envolvidos sabiam do risco em enunciar seu uso. Entretanto, na ocasião de nossa visita, o Padrinho Sebastião, seu filho Padrinho Alfredo e outros adeptos do grupo não se furtaram a conceder entrevistas sobre o uso da Santa Maria, dizendo que era por meio desta substância que se pautava todo um princípio de Educação na comunidade, que o uso ritual da Santa Maria era comum entre as famílias e que as reuniões familiares para esta finalidade eram importantes para a união e o respeito entre gerações. Pudemos filmar cenas destes rituais com muita naturalidade.

Quando chegamos ao Rio de Janeiro e começamos a editar o material, começamos a nos perguntar como deveríamos tratar as cenas e as entrevistas relativas ao uso da "Santa Maria". Se, por um lado, as pessoas pesquisadas não nos tinham interditado em utilizar estas cenas na edição do filme, por outro lado, sabíamos que o assunto era polêmico e que a divulgação do uso em rituais de uma planta discriminada e repleta de significações negativas no contexto do imaginário urbano poderia gerar problemas para a comunidade. Com o tempo, descobrimos que no universo ayahuasqueiro da Amazônia, a comunidade do Santo Daime era discriminada por outras 
comunidades que faziam uso ritual da bebida, exatamente por utilizarem a "Santa Maria".

Havia uma estratégia dos simpatizantes da "Comunidade do Santo Daime" de evitar que a "ayahuasca" viesse a integrar a lista dos entorpecentes proscritos por lei. Esta estratégia envolvia vários especialistas. Eu mesma cheguei a participar, como antropóloga, de um Seminário juntamente com os juristas Técio Lins e Silva e Nilo Batista e o psicanalista Eduardo Mascarenhas onde se procurava debater a questão do uso de determinadas substâncias consideradas psicoativas por diferentes grupos sociais. Minha colaboração foi exatamente trazer o foco para a questão da cultura, contextualizando o uso da "ayahuasca" na Comunidade do Santo Daime. ${ }^{11}$

Esta estratégia parecia funcionar com relação ao uso da "ayahuasca" na medida em que havia efetivamente um desconhecimento sobre as substâncias encontradas nas plantas utiizadas para a infusão da bebida ritual. Pesquisas eram feitas e o que se concluía era que as substâncias encontradas não eram compatíveis com os alucinógenos já conhecidos. Estes estudos médicos somados aos estudos antropológicos e históricos, além dos pontos de vistas de psicanalistas e psicólogos envolvidos no debate evitavam que o uso da "ayahuasca" fosse proscrito, pelo menos integralmente. Avaliava-se sobretudo o caráter cultural e ritual do uso da bebida e sua ampla difusão na região amazônica.

Mas, como lidar com o fato de que a comunidade também fazia uso ritual da "cannabis sativa", substância proscrita? E o que fazer com as imagens e os depoimentos que iam sendo editados? Num primeiro momento, decidi conversar com Gilberto Velho e Luiz Fernando Dias Duarte, dois experientes antropólogos do contexto urbano, que naquela altura eram meus professores no Mestrado em Antropologia Social no PPGAS/Museu Nacional/UFRJ. Gilberto conversou comigo sobre sua tese de Doutorado, "Nobres e Anjos. Um Estudo de Tóxicos e Hierarquia", onde procurou mapear estilos de vida e visões de mundo de dois grupos das camadas médias cariocas da Zona Sul da cidade do Rio de Janeiro. Neste estudo, o antropólogo focalizou o uso dos "tóxicos", particularmente da cocaína e da maconha nestes grupos, pois estes funcionavam como porta de entrada para os estilos de vida e as visões de mundo

\footnotetext{
${ }^{11}$ Ver o artigo originado pela palestra proferida na ocasião: ABREU, Regina. "Plantas Psicoativas: Símbolos de Identidade Social”. In: GONÇALVES, Odair Dias; BASTOS, Francisco Inácio. (Org.). Só Socialmente. 1ed, v. 1. Rio de Janeiro: Relume Dumará, 1992. p. 5-30.
} 
analisadas. ${ }^{12}$ Disse-me que tinha decidido não publicar a tese escrita em 1975 , pois os informantes seriam facilmente identificáveis e que um dos papéis do antropólogo era também proteger a população pesquisada. ${ }^{13}$ A Antropologia e, especificamente, a Antropologia Visual não podia servir para o enquadramento criminal das pessoas que confiaram a nós os seus "segredos".

Seguimos o conselho. Entretanto, na edição do vídeo, Noilton e eu mantivemos a estrutura dos princípios do masculino e do feminino, importantes para o sistema de crenças da Comunidade do "Santo Daime". ${ }^{14}$ Decidimos também fazer duas versões: uma, com as cenas do uso da "cannabis" e outra, onde estas cenas eram susbtituídas por outras. Demos o título de "Daime Santa Maria" para o vídeo. A primeira versão era projetada em pequenos círculos, em seminários com a presença de antropólogos e outros especialistas. Servia assim para amadurecer entre especialistas a questão do uso social de plantas psicoativas. A segunda versão foi amplamente difundida para todos os públicos. Nesta última versão, procuramos enfatizar o contexto cultural da vida na comunidade e seus rituais. O vídeo se tornou um ícone da descoberta da "Comunidade do Santo Daime" e um dos poucos trabalhos onde aparecem imagens de seu fundador, o Padrinho Sebastião que faleceu alguns anos depois. A "Comunidade do Santo Daime" expandiu-se enormemente e eu tenho a certeza de termos feito a opção mais correta. Assim como Gilberto Velho, de saudosa memória, não nos furtamos à reflexão que as imagens traziam, mas também não expusemos a população. ${ }^{15}$

Outro aspecto importante foi que disponibilizamos cópias das duas edições e de todo o material para o grupo pesquisado. Entretanto, esta ação não teve a repercussão que esperávamos, uma vez que na Amazônia a umidade é enorme e a comunidade não tinha (como ainda não tem) condições técnicas de armazenamento de vídeos. Os rápidos avanços tecnológicos levaram ainda que os suportes das fitas em U-matic (alguém se lembra deste formato?) ficassem obsoletos e muito do material se estragasse. Além disso, havia disputas entre grupos associados à comunidade que não se entendiam sobre onde e com quem afinal deviam ficar as fitas. Em suma, se não fosse o nosso cuidado

\footnotetext{
${ }^{12}$ VELHO, Gilberto. Nobres e Anjos. Um Estudo de Tóxicos e Hierarquia. Rio de Janeiro: Fundação Getúlio Vargas Editora., 1988.

${ }^{13}$ A tese só foi publicada em 1988 , ver op. cit.

${ }^{14}$ ABREU, Regina. "Daime Santa Maria: Uma Antropologia de Audios e Imagens". In: Comunicações do Iser, v.10, n.1. Rio de Janeiro: ISER, 1984. p. 36-46.

${ }^{15} \mathrm{Na}$ ocasião, escrevi um artigo focalizando a trajetória de perseguição policial ao uso das plantas psicoativas na Comunidade do Santo Daime na Amazônia. ABREU, Regina. "Santo Daime". In: LANDIM, Leilah. (Org.). Diversidade Religiosa no Brasil. 1ed. Rio de Janeiro: Instituto Superior de Estudos da Religião, 1990.
} 
em preservar o material editado, não teríamos mais nenhuma cópia desta documentação, o que nos sinaliza que a ideia de "devolução" física de filmes para a população pesquisada nem sempre é exitosa. Hoje, penso que qualquer material que envolva a tecnologia de filmes deve mesmo ser preservado por instituições com tecnologia própria para isto. A "devolução" pode vir de outras maneiras, organizando sessões com eles, contribuindo para ampliar as reflexões e, em alguns casos, mediando conflitos e negociações entre eles e outros agentes e instituições.

Links do filme "Daime Santa Maria" dirigido por Noilton Nunes e Regina Abreu:

http://www.youtube.com/watch?v=RLCNzYsr30Q http://www.youtube.com/watch?v=f4ydK_lvAsI http://www.youtube.com/watch?v=uxdvw-jqxes http://www.youtube.com/watch?v=WXbKwZq82v0 http://www.youtube.com/watch?v=BSuQyxg9Kjw http://www.youtube.com/watch?v=I83VdpfQ-_E http://www.youtube.com/watch?v=vvvpt5dF0WM

\section{"Canibalizando" a cena ou quando o "nativo" inverte o jogo e recusa o lugar passivo do "entrevistado":}

A segunda experiência do impacto do audiovisual e particularmente do desempenho da câmera como "personagem" durante uma filmagem que eu gostaria de relatar ocorreu no Xingu em julho de 2003. Eu filmava também com o cineasta Noilton Nunes, o ritual do Quarup em homenagem a Orlando Villas Boas na Aldeia Yawalapti. Minha participação na equipe era na condição de Consultora de Antropologia e na Produção do filme. Trabalhava basicamente na elaboração do roteiro das filmagens e na pesquisa sobre o ritual para contextualizar e indicar as cenas que deveriam ser filmadas para a compreensão e a valorização do evento. A iniciativa do filme havia partido de um grupo de simpatizantes da "causa indígena" que mantinham contato estreito com o grupo Kamayurá, em especial, com o Pajé Sapaim. 


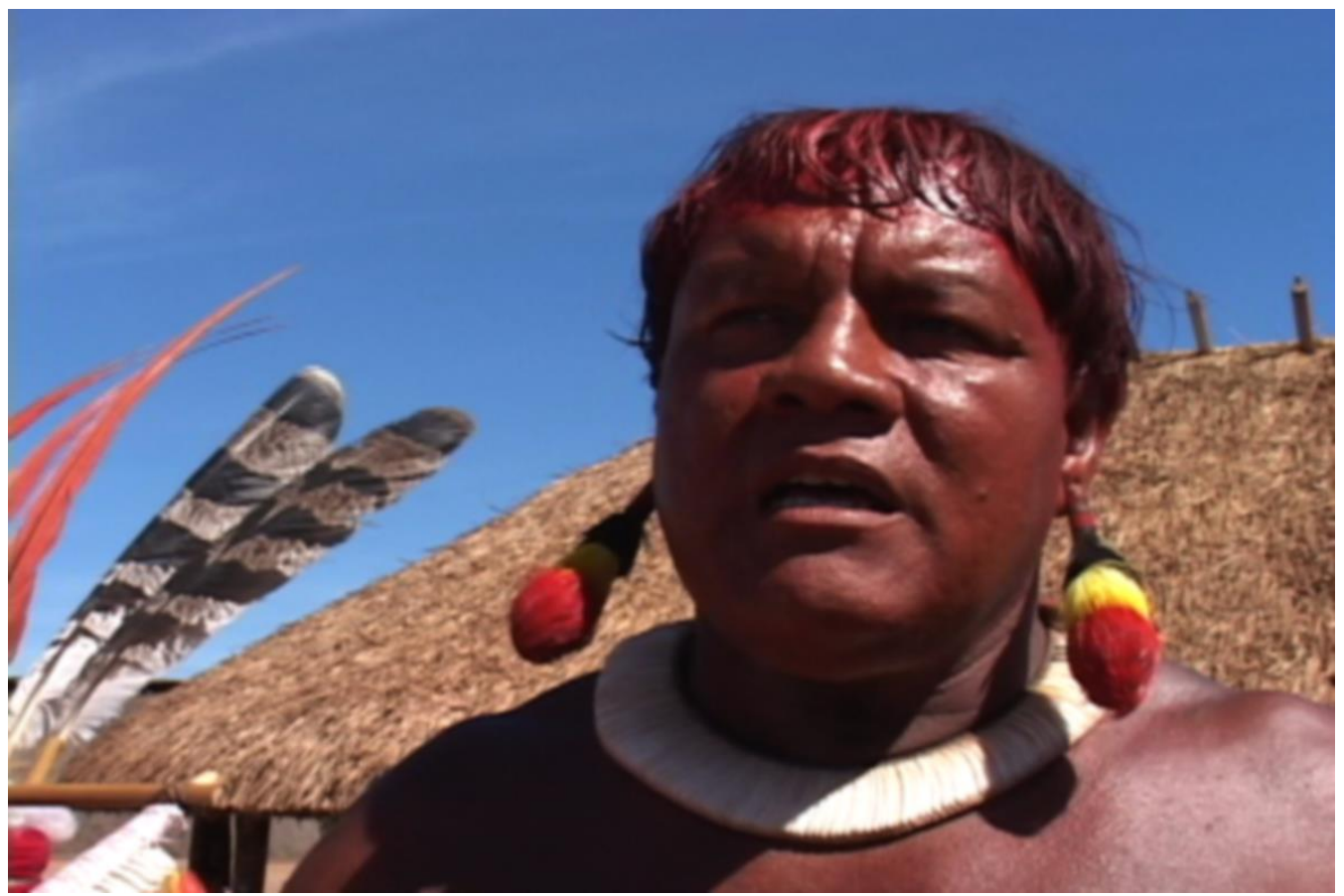

4. Cacique Aritana. Foto de Regina Abreu, julho de 2003.

Logo que chegamos, fomos recebidos pelo Cacique Aritana da aldeia Yawalapiti. Era nesta aldeia que o Quarup se realizava e Aritana representava sua maior liderança. Como éramos convidados do Pajé Sapaim que vinha a ser tio de Aritana, a negociação sobre nossa filmagem, hospedagem e devolução do trabalho para a aldeia já estava de certo modo implícita. Já estava previsto que ficaríamos na casa dos familiares do Pajé Sapaim e não havia nenhum impeditivo com relação ao nosso trabalho. Entretanto, a recepção de Aritana em sua casa, cercado por outras lideranças e, em particular, assessorado por seu filho mais velho e sucessor, se revestia de grande pompa e circunstância. Havia um aspecto performático na chegada à casa do Cacique: nós com nossas câmeras e muitos presentes para Aritana e sua aldeia diante daquele um grupo de homens altos, fortes, portentosos. Logo, ele soube exercer sua autoridade, quando chegamos, tínhamos a câmera ligada, pronta para registrar aquele momento, mas ele ordenou que a desligássemos. Indagou ritualmente o que nos trazia ali, para que filmaríamos e chamou a atenção para a necessidade de apoio, de problemas que estavam tendo com o Governo do Mato Grosso, com o desmatamento na região, com o excesso 
de agrotóxicos utilizados no plantio de soja que vinham contaminando toda a área do Parque do Xingu. O Cacique era firme em seus propósitos e falava com voz mansa: "vocês vão ficar aqui, podem filmar, mas tem que ajudar o índio." Ele chamava a atenção, por diversas vezes, que havia uma certa confusão "do lado do branco", que cada Governo falava uma coisa e que, em suma, precisava de auxílio. Foi muito cordial, mas deixou claro que era a autoridade no local e que esperava algo em troca das nossas filmagens.

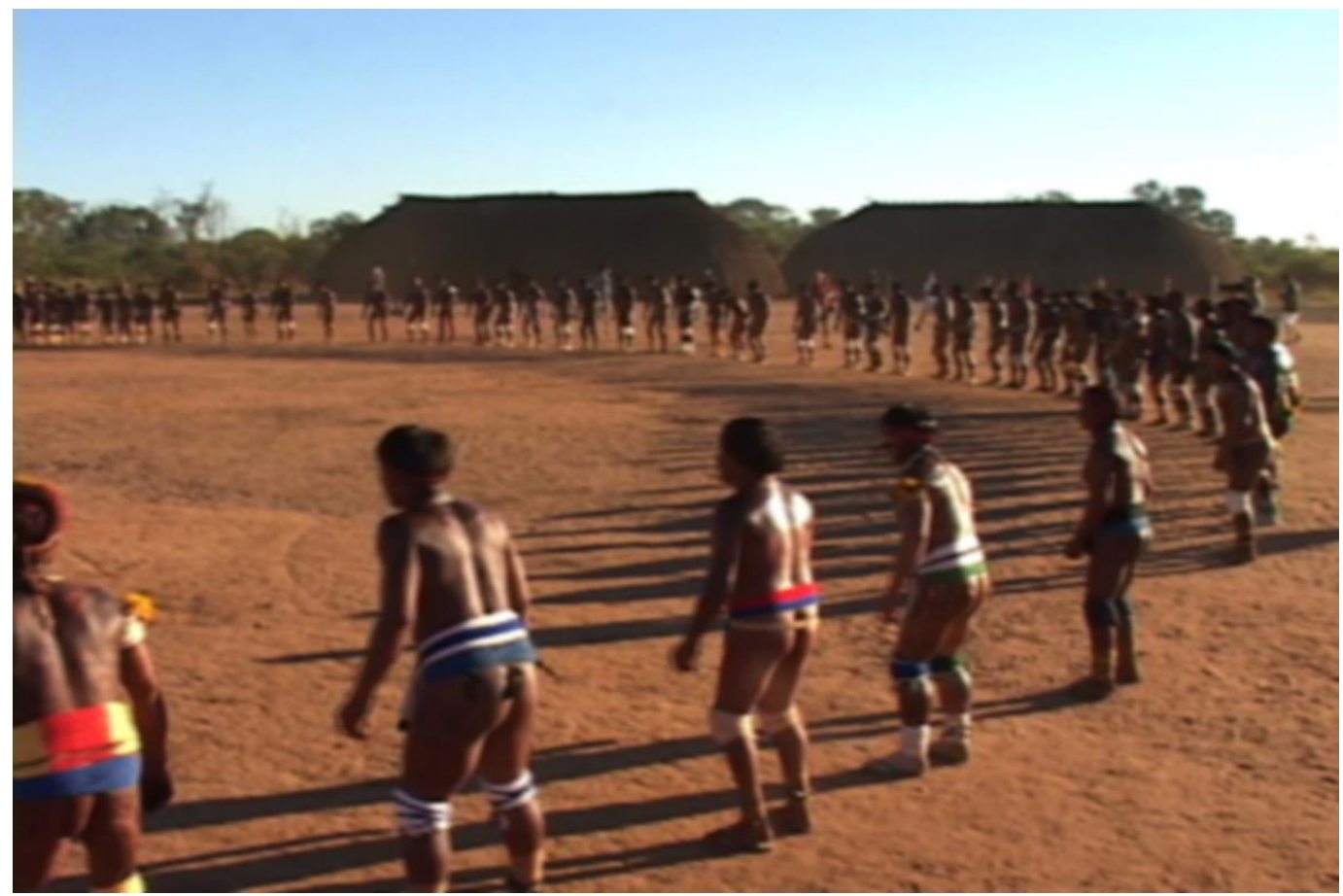

5. Ritual na Aldeia Yawalapti Xingu. Foto de Regina Abreu, julho de 2003.

O ritual já havia começado, os visitantes de outras aldeias já estavam chegando, o tronco já estava no centro da aldeia, os cantores já rezavam em cantavam à sua volta tocando seus maracás num ritmo compassado. O cacique Aritana comandava o espetáculo com um senso de direção de um grande performista. Para mim, ia ficando cada vez mais evidente a consciência plena de Aritana e de outras lideranças indígenas das etnias presentes da importância performática e comunicativa daquele ritual já 
devidamente transformado em espetáculo. Era impressionante o número de fotógrafos e cinegrafistas presentes. Muitos eram estrangeiros, alemães, franceses, ingleses, americanos. Alguns eram ligados a jornais e televisões brasileiras. O programa Expedições da Paula Saldanha lá estava realizando mais um episódio de sua série para a TV. A TV Globo lá estava com todo seu aparato, cinegrafistas, repórteres, equipamentos sofisticados. O Cacique Aritana e outras lideranças indígenas detinham total controle da situação e sabiam bem o que queriam mostrar, como queriam mostrar, para que queriam mostrar e para quem queriam mostrar todo aquele espetáculo. $\mathrm{O}$ ritual já há muito deixou de ser um ritual interno aos grupos indígenas para se transformar num momento midiático de grande expressão. Inclusive, naquele ano, inovavam, pois em geral, o Quarup é realizado para homenagear um Cacique falecido há um ano. É um ritual que marca o fim do luto na aldeia, que libera a aldeia para a vida do dia-a-dia, sem as interdições relacionadas ao período após a morte. Era a primeira vez que homenageavam um "cacique branco", como eles diziam. Argumentavam sobre a importância de Orlando Villas Boas para a aldeia e recriavam a tradição. Eles sabiam muito bem o alcance e a repercussão que um ritual cheio de cores, dança, música e a singularidade esfuziante da terra vermelha, do sol, das estrelas, dos índios xinguanos, poderia ter num mundo globalizado e midiatizado. Fui percebendo o quanto os caciques, as lideranças, e principalmente, os jovens, relacionavam-se bem com os aparelhos digitais, as câmeras, as fotografias e sobretudo com o poder da imagem. Para mim, era uma oportunidade única, pois eu havia sido convidada por amigos dos índios e ficaria entre eles. Fiquei hospedada numa grande casa xinguana, tendo como anfitriões uma família de índios yawalapti com laços de parentesco com índios kamayurá. Nossa condição de convidados nos dava certa liberdade com relação ao controle permanente que as lideranças indígenas exerciam junto às equipes de filmagens que ali estavam. Havia também muitos amigos de Orlando Villas Boas e membros de sua família, integrantes de instituições como o Museu do Índio e a Funai. Representantes do Governo do Mato Grosso e até mesmo fazendeiros da região. Para além do ritual propriamente dito, ocorriam fatos curiosos como a presença do filho do Mario Juruna, que ali estava porque uma equipe rodava um filme sobre o antigo deputado indígena. Festejavam a participação de um Xavante num Kuarup no Xingu, fato raro, devido a uma antiga rivalidade entre os Xavante e algumas etnias do Xingu. O encontro entre diversas etnias xinguanas e os Xavantes marcavam assim um encontro de paz. Enfim, acontecia de tudo um pouco nos mais ou menos dez dias que durou aquele ritual. Para 
mim e para nossa equipe, a interlocução com o Cacique Aritana e outras lideranças indígenas era muito facilitada pelo Pajé Sapaim Kamayurá. Não havia um "contrato", não havia um pagamento combinado (como ocorreu com outras equipes). Havia um acordo tácito de trocas, principalmente com o Pajé Sapaim, que nas ocasiões em que vinha ao Rio de Janeiro hospedava-se na casa de um de nossos amigos.

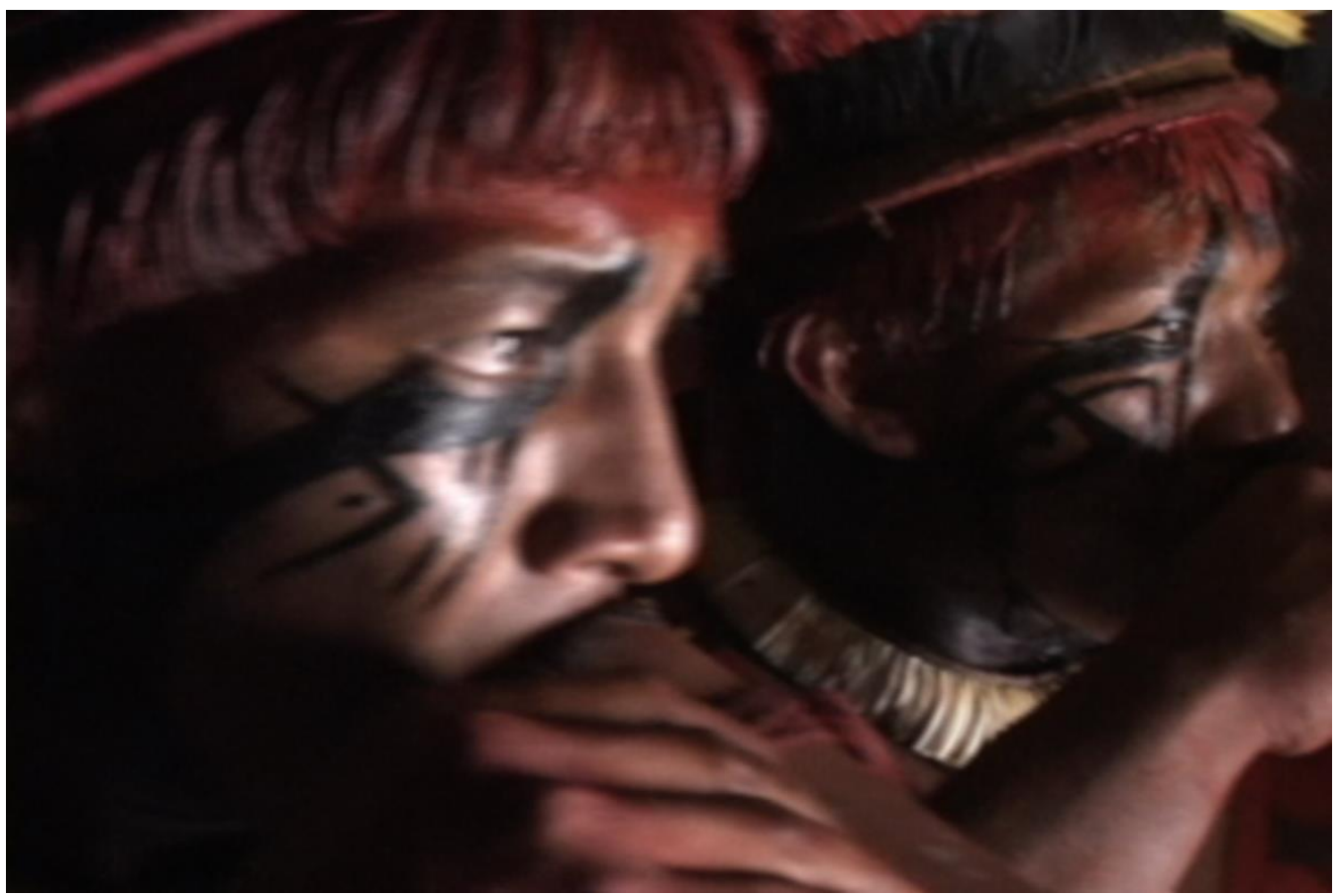

6. Tocadores de Flauta. Foto de Regina Abreu, julho de 2003.

Mas, o que mais me chamou a atenção em toda esta experiência foi a relação dos índios e, em particular, do Cacique Aritana com a "câmera" à sua frente. E eram muitas! Muitas mesmo, de todos os tipos e de todas as nacionalidades. E com todas as intenções. E todas as perguntas. E todos os anseios de desvendamento, dissecamento, exposição do novo, do sensacional, do diferente. Mas, o Cacique Aritana demonstrava saber bem o que queria. E, particularmente, tinha uma sensível representação do poder de uma "câmera", de um filme, de uma imagem projetada. Um fato singular me marcou profundamente. O ritual transcorria ritmado com uma grande cantoria. A pintura do tronco já havia sido finalizada. Os cantores invocavam os entes sagrados. De repente, 
abriu-se uma enorme roda e os guerreiros com o corpo todo pintado de urucum, faixas coloridas em vermelho e amarelo na cintura, enfeitados com seus colares e portando belíssimos cocares, passaram a marcar o ritmo pisando forte no chão. A roda girava com energia e vitalidade. Sentia-se que algo importante iria acontecer. Neste momento, passsei a reparar na dança frenética das câmeras, na ansiedade estampada nos rostos dos cinegrafistas e repórteres presentes. Todos ali prontos para devorar a cena, o fato, a palavra, a imagem singular. É neste momento que o repórter e o cinegrafista de uma TV ali presente aproximam-se do Cacique Aritana e buscando o furo de reportagem posicionam a câmera à sua frente, disparando a pergunta: "- e, então, Cacique Aritana, o espírito de Orlando Villas Boas está chegando? Ele vai baixar?" Aritana, com uma postura altiva, soberano do alto de seus quase dois metros de altura e de seu enorme e majestoso porte, nu, com uma grossa faixa vermelha e amarela na cintura e pintado de urucum de cima a baixo, empunhando seu celular na mão direita, que não se intimida e responde: "Sim, ele está chegando e quer mandar um recado para o Governo. O Governo precisa cuidar dos nossos rios. A poluição está acabando com o rio. As nossas crianças estão bebendo água contaminada dos venenos que vêm das fazendas. Cada um fala uma coisa. O Governo não está se entendendo. E o meu povo é que está sofrendo. Precisamos preservar nosso rio, preservar a nascente do rio que está nas fazendas de soja e que vai acabar com nosso povo se o Governo não tomar providências. "Enfim, contrariando às expectativas dos mais ingênuos, o Cacique Aritana demonstrava que sabia com quem estava falando. Ou melhor, que conhecia o poder de uma "câmera", de uma televisão, e sabia o que precisava falar para ela. Demonstrava total conhecimento dos códigos midiáticos e não se intimidava. Invertia o jogo. O observado tomava uma postura ativa. Fizesse o que quisesse com aquela entrevista, mas a TV teria que dar voz e escutar os reais anseios por trás daquela imagem de um indígena "em carne e osso". Eu nunca tinha participado de um momento tão intenso de inversão no ato da filmagem, quando o entrevistado vira a mesa, subverte e traz o seu próprio olhar e a sua própria fala, fazendo o interlocutor calar, deixando-o estupefato, sem ação. Neste momento, eu percebia com absoluta nitidez o caráter performativo da filmagem, testemunhando uma reação inesperada do entrevistado, que mudando o curso dos acontecimentos, transformava a cena num espaço de repercussão para todos que ali estavam. Pouco importava o que seria feito com aquele material. $O$ grande ato, o climax do ritual para mim aconteceu ali naquele momento. Dezenas de câmeras gravaram aquele momento. A homenagem a Orlando Villas Boas transformou-se num ato político de grande 
envergadura. Foi também nessa hora que percebi o quanto era importante o ponto de vista antropológico. O breve instante em que se passou esta cena pode ter passado desapercebido para muitos. Era um ato da ordem do "imprevisível", algo que fugia do script, uma atitude que escapava completamente ao ritual. Talvez muitos não percebessem, mas o conhecimento da literatura sobre a cosmologia xinguana me trazia informações relevantes para que eu percebesse a grande "jogada" de Aritana. Ocorre que, diversamente dos rituais relacionados a mortos no Ocidente, o Quarup não invoca o morto em sua individualidade, mas em seu aspecto holista, cosmológico. O morto é parte indissociável do cosmos e, como tal, ele não tem mais rosto, nem individualidade próprias, ele não é uma "alma" como os cristãos concebem. O mundo dos caciques que já morreram é parte de um mundo natural que veio das águas e para as águas retornará. Portanto, a pergunta do repórter da TV era completamente anacrônica naquele contexto. Espíritos de caciques não "baixam", não "retornam" como na cosmologia espírita. Espíritos de caciques não existem desse modo como imaginamos em nossa tradição judaico-cristã.

Passado o ritual, acompanhei a luta dos povos do Xingu pela despoluição de seus rios e pelo "tombamento" das nascentes dos rios que alimentam as aldeias. Esta luta se transformou numa das principais bandeiras das lideranças xinguanas e prossegue ainda em nossos dias. Em 2010, obtiveram uma conquista: os dois lugares sagrados para as comunidades indígenas do Alto-Xingu, no Mato Grosso, Sagihengu e Kamukuwaká, tornaram-se patrimônio cultural do Brasil. O Conselho Consultivo do Patrimônio Histórico aprovou, por unanimidade, o pedido de tombamento apresentado pelas etnias Waurá, Kalapalo e Kamayurá e reforçado pelo Instituto do Patrimônio Histórico e Artístico Nacional - Iphan. ${ }^{16}$

O material que filmamos foi usado em diferentes momentos neste processo de luta dos povos xinguanos. Foi editado num filme chamado "Kuka Hitchuti - Você já abriu os olhos?", onde procuramos fazer um relato do que se passava no ritual a partir de um depoimento de Yanacolá que discorre sobre os principais momentos do ritual. Mas, introduzimos algumas cenas do que eu chamaria de "meta-ritual", tudo aquilo que acontecia à volta e que, de algum modo, era também incorporado pelo ritual. É interessante observar como nós, antropólogos, fotógrafos, cinegrafistas, repórteres,

\footnotetext{
${ }^{16}$ http://portal.iphan.gov.br/portal/montarDetalheConteudo.do?id=15201\&sigla=Noticia\&retorno=detalhe Noticia.
} 
fomos de certo modo "antropofagizados" e incluídos como elementos ativos do Quarup. $^{17}$

Link do filme "Kuka Hitchúti: Você já abriu os olhos?"

http://www.youtube.com/watch?v=R5CfMJSTMa4

\section{O "poder" da câmera}

As últimas experiências que eu gostaria de relatar foram mais recentes, relacionadas ao projeto "Museus do Rio", iniciado em 2007, no Estado do Rio de Janeiro. Este projeto envolve uma equipe interdisciplinar com a participação basicamente de historiadores, antropólogos, museólogos. Trata-se de um projeto voltado para a formação de jovens pesquisadores, incluindo bolsistas de Iniciação Científica da disciplina "Antropologia dos Museus". Em linhas gerais, é um projeto que tem como objetivo pesquisar os museus no Estado do Rio de Janeiro e, concomitantemente, na medida em que a pesquisa vai avançando construir um banco de dados sobre os museus na sua relação com as localidades em que se situam. Um dos motes centrais é refletir sobre os museus como "personagens" que habitam determinada região e que, nesta condição, expressam narrativas sobre pessoas, coisas e territórios. Desvendar estas narrativas tem sido um dos objetivos da pesquisa. O projeto disponibiliza um portal com um conjunto das informações que vão sendo reunidas www.museusdorio.com.br. O audiovisual desempenha papel central, permitindo a produção de imagens do entorno, dos museus e a realização de entrevistas com aqueles a quem chamamos de "guardiãos da memória", narradores privilegiados pela condição de serem antigos moradores ou pela militância com a causa da memória. Estes narradores são sempre escolhidos a partir de pesquisas prévias, por meio de teses, dissertações, livros ou referências de redes de técnicos de museus e patrimônios. Com estas pesquisas prévias, garantimos que as pessoas entrevistadas sejam aquelas que mantêm uma relação orgânica com os museus, suas coleções, seu prédio e, na maior parte das vezes, com a localidade em que estes se inserem. O uso do audiovisual também é importante porque os objetos, as

\footnotetext{
${ }^{17}$ Para maiores detalhes, ver: ABREU, Regina. "Eterno Kuarup, patrimônio cultural xinguano". In: LOPES, Antonio Herculano (org.) Religião e Performance ou As Performances das Religiões Brasileiras. v.1, cap.10. Rio de Janeiro: Contra-capa, 2007. p. 185-195.
} 
fotografias, as diferentes formas arquitetônicas encontradas nos museus também nos contam histórias, muitas eminentemente visuais.

Muitas vezes não nos damos conta do que significam nossas presenças em pequenas cidades do interior do estado, quando chegamos num micro-ônibus com logomarca da Universidade, trazendo câmeras, máquinas fotográficas juntamente com nossos olhares curiosos. O audiovisual pode ser muito expressivo em certos contextos. Empunhar uma câmera diante de alguém pode provocar reações que na maioria das vezes não controlamos, despertando um sem número de representações sobre o nosso trabalho. Como, na maior parte dos casos, nossos interlocutores não conhecem bem o que significa uma pesquisa antropológica, somos identificados como repórteres, documentaristas ou jornalistas, o que pode provocar sérios mal-entendidos. O fato de chegarmos num micro-ônibus da Universidade também nos identifica com o poder público, o que nos vincula ao Estado e à possibilidade de eventualmente intervir em questões locais.

A primeira experiência se deu na pequena cidade de Conservatória, na região do Médio Paraíba. Nesta pequena cidade, curiosamente, há muitos museus. A cidade vive de uma espécie de "dividendos" de um trabalho com a memória, uma vez que lá foi inventada uma "tradição de serestas". A história que se conta no local é que dois irmãos decidiram dinamizar a cidade criando um ritual de serestas nos finais de semana. Para isto, colocaram plaquinhas com nomes de músicas próprias para serestas nas portas das casas. Um grupo de músicos passou a percorrer as casas parando em cada porta e cantando a música respectiva da plaquinha afixada. A atividade foi ganhando enorme sucesso, com os compositores das respectivas músicas se dirigindo à cidade para serem homenageados, com a afluência de turistas ao local e com a consequente dinamização do comércio que passou a girar em torno das serestas. Conservatória tornou-se assim conhecida como a "cidade das serestas", atraindo empreendedores, como o Sr. Volney, que decidiu organizar diversos museus de compositores expressivos, como Sílvio Caldas entre outros. A popularidade dos dois irmãos, "os irmãos Freitas", cresceu enormemente e a grande afluência de pessoas que chegavam aos finais de semana para as serestas se dirigia para a casa de um deles que passou a aglutinar o ponto de partida das serestas. Com o tempo, as pessoas começaram a colar fotografias, material de imprensa, cartazes, cartas nas paredes da casa e também a depositar objetos ligados aos eventos das serestas. Devido ao motivo de ir armazenando um conjunto significativo de 
objetos ligados às atividades das serestas, o local passou a ser conhecido como "Museu da Seresta". ${ }^{18}$

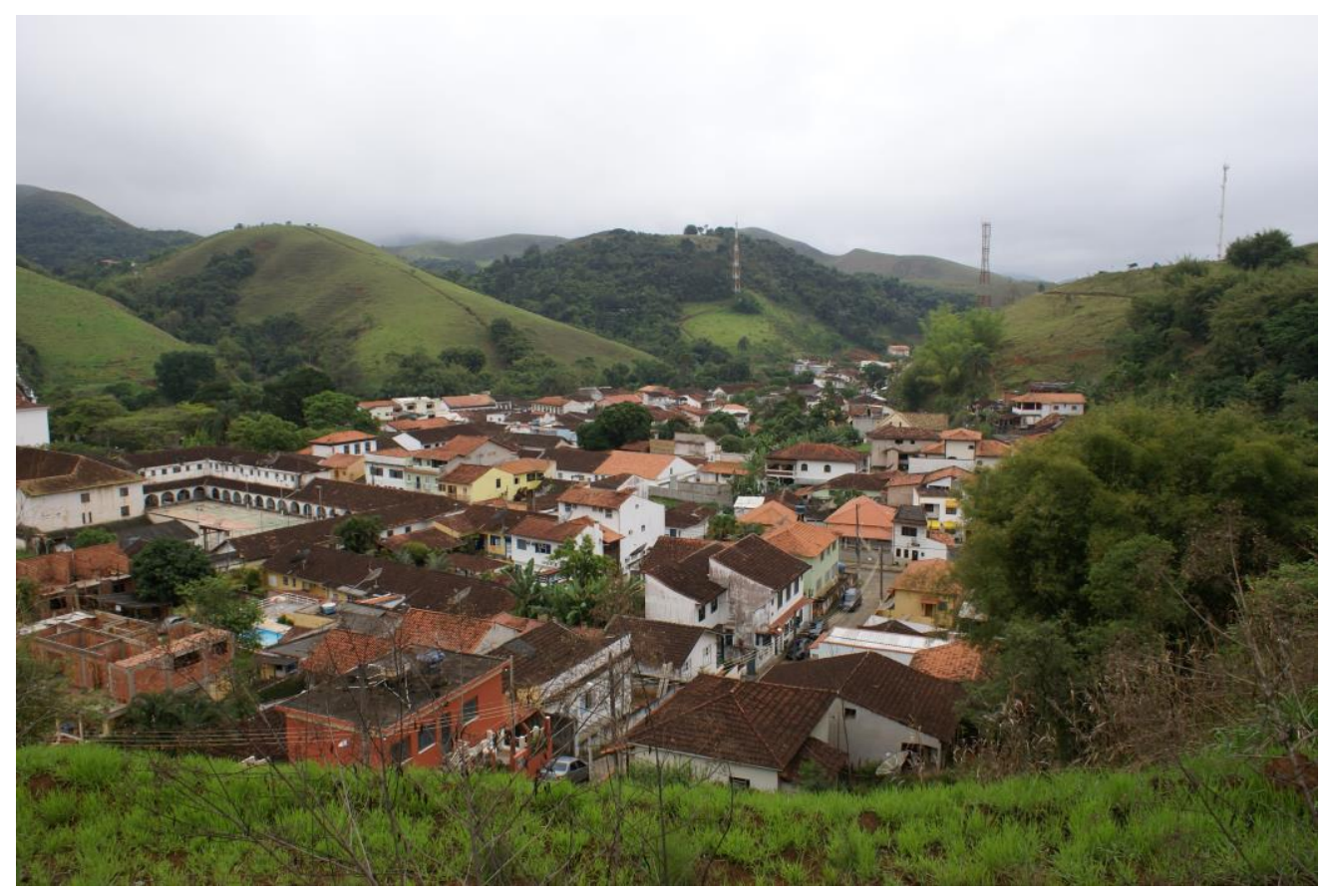

7. Cidade de Conservatória vista de cima. Foto de Regina Abreu, 2007.

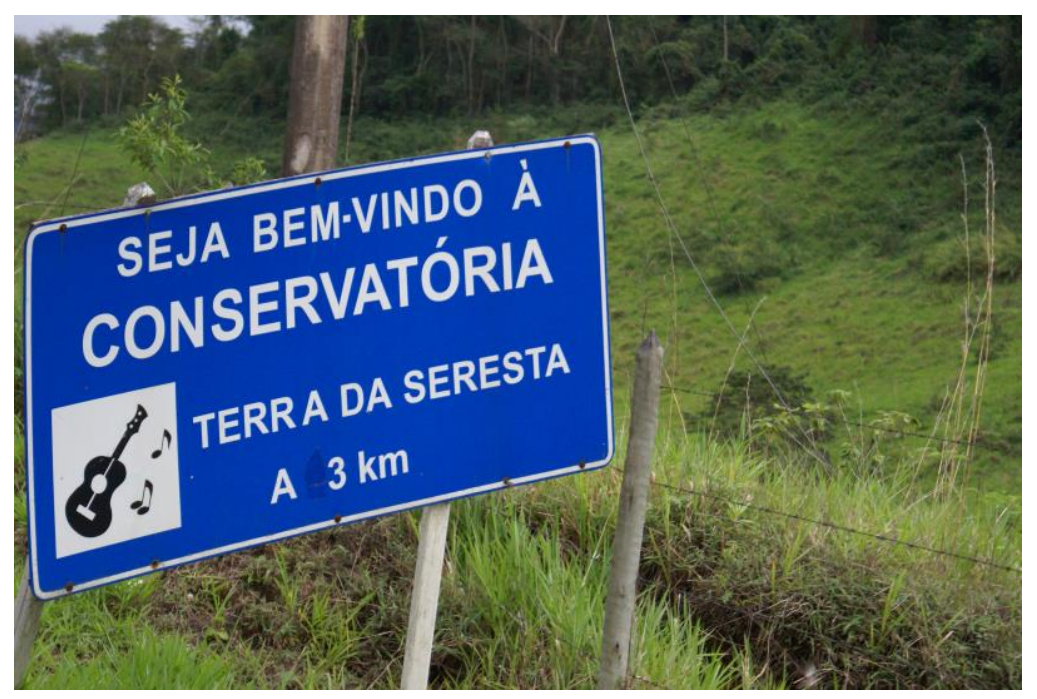

8. Placa de Conservatória. Foto de Regina Abreu, 2007.

18 http://www.museusdorio.com.br/joomla/index.php?option=com_k2\&view=item\&id=14:museu-da$\underline{\text { seresta-e-da-serenata\&Itemid=213 }}$

http://www.seresteiros.com.br/museu.htm 


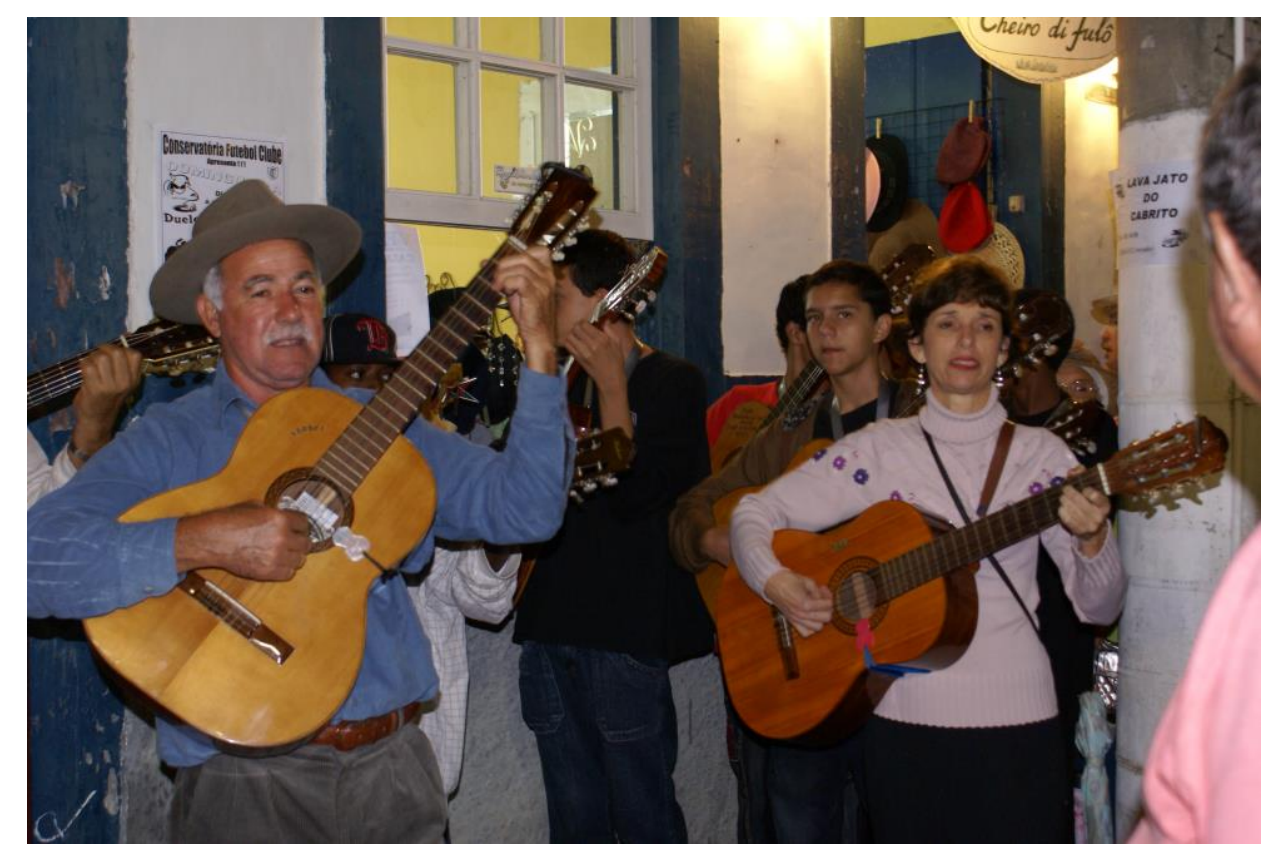

9. Seresta em Conservatória. Foto de Regina Abreu, 2007.

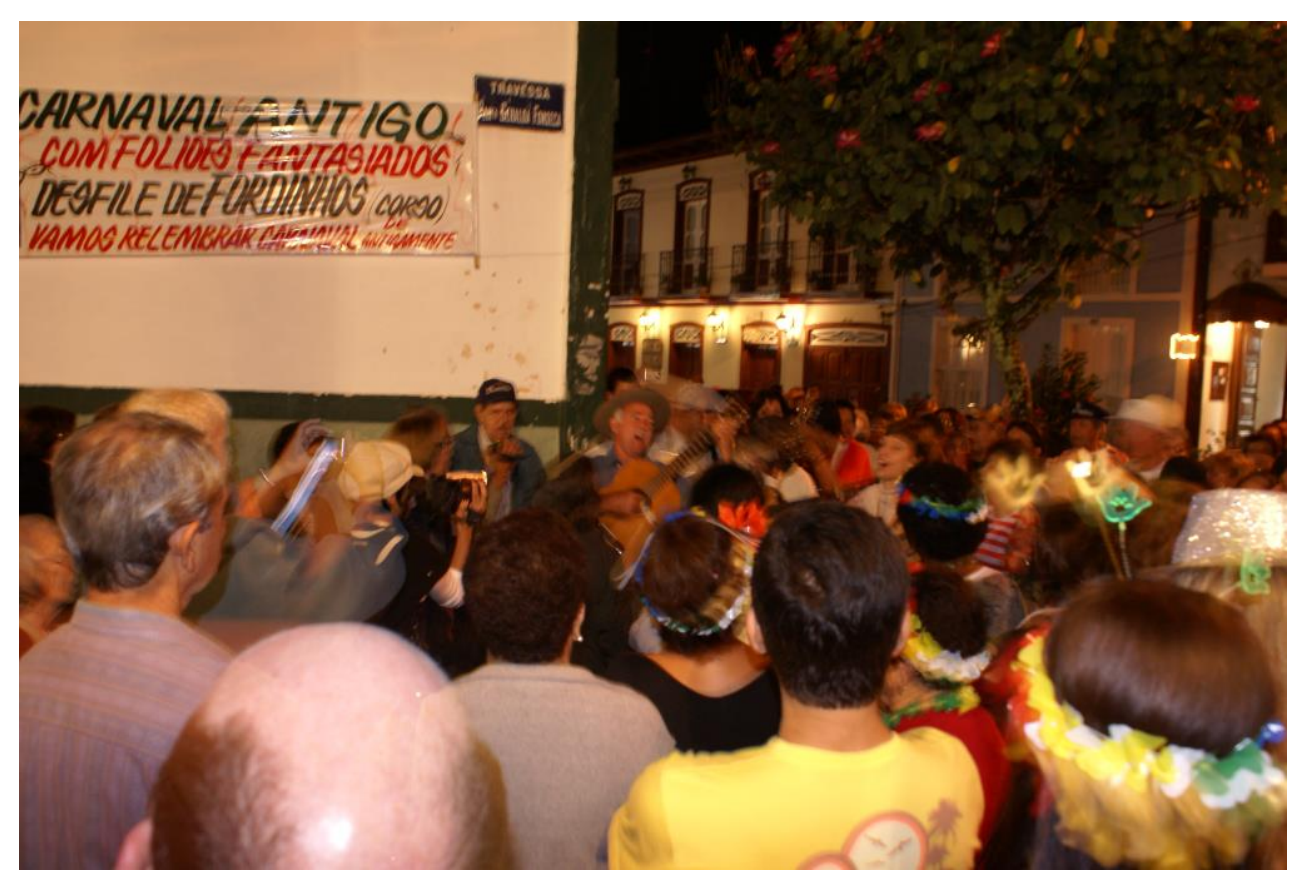

10. Seresta em Conservatória. Foto de Regina Abreu, 2007.

Um tempo mais tarde, um dos irmãos, proprietário da casa em questão, faleceu e sua viúva continuou dando andamento às atividades da seresta e preservando o 
"museu". Quando chegamos na cidade, fomos diretamente ao "Museu da Seresta", pois havíamos marcado uma entrevista com sua "diretora", a esposa de um dos "irmãos Freitas". Esta nos recebeu gentilmente, mas percebia-se em sua entrevista um tom um tanto reativo às nossas perguntas. Quanto mais indagávamos sobre o "museu" - seu funcionamento, sua trajetória, suas histórias - mais ela se mostrava pouco à vontade, repetindo diversas vezes: "- isto aqui é um ponto de encontro de seresteiros! Esta é uma casa particular, mantida por mim e por meus filhos. Eu vivo de salário e mantenho esta casa com muito esforço. A Prefeitura não me dá um tostão". Logo percebemos que ela havia nos associado ao poder público e a nossa presença personificava um certo fantasma de uma possível desapropriação da casa. Fizemos outras entrevistas, documentamos o movimento da seresta. Mas, a entrevista com a "diretora do museu" havia nos trazido certo desconforto. Voltamos para a Universidade, começamos a editar o material e, ficamos com a sensação de que ela nos havia identificado com um Poder Público inoperante que "não dá um tostão", "cobra impostos" e ainda representa um imaginário de arbitrariedade. Este (des)encontro com um interlocutor em nossa pesquisa nos fez refletir sobre a necessária clareza que devemos ter numa pesquisa, principalmente ao utilizar o registro audiovisual. Por outro lado, nos pareceu que a filmagem estimulou a diretora a expressar este incômodo com o poder público, o que trouxe uma nova questão até então não pensada por nós no projeto: esta difícil relação entre público e privado no contexto dos museus. 


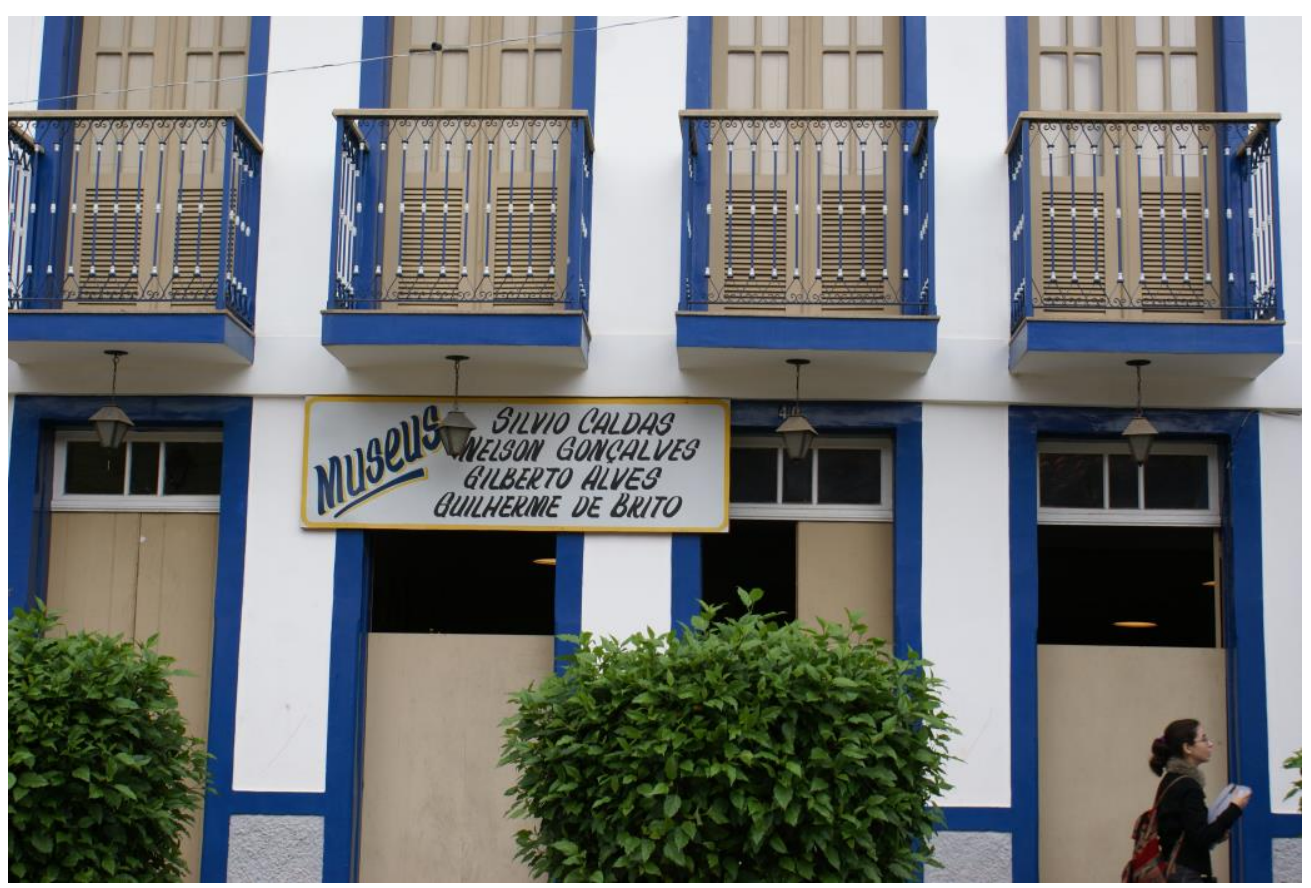

11. Placa do Museu de Conservatória. Foto de Regina Abreu, 2007.

A outra experiência ocorrida também neste projeto, numa outra pequena cidade do interior do Rio, revela uma situação semelhante, porém, com resultados invertidos. Após ter visitado o "Museu Von Martius" ${ }^{19}$ no Parque Nacional da Serra dos Órgãos, em Teresópolis, paramos para almoçar, quando fomos abordados por um casal já idoso e um rapaz de meia idade. Eles integravam uma Associação de Moradores de Guapimirim e traziam um dossiê com imagens de pinturas do pintor Henrique Bernardelli. Faziam uma solicitação para nossa equipe. Segundo eles, havia uma casa nas imediações que havia pertencido ao pintor e onde este havia pintado um painel retratando figuras alegóricas que depois teria sida reproduzida em um de seus famosos quadros. Sem herdeiros, após sua morte, a casa teria caído numa situação de abandono. A Associação que nos procurou, percebendo a relevância histórica da casa alentava um projeto de transformá-la em um centro cultural. Entretanto, a casa havia sido ocupada,

\footnotetext{
${ }^{19}$ A antiga casa-sede da fazenda Barreira do Soberbo, no Parque Nacional de Serra dos Órgãos, abriga hoje um museu em homenagem ao botânico e naturalista alemão Friedrich Philipp Von Martius. Um dos membros da missão científica enviada ao Brasil pelos governos bávaro e austríaco, em 1817, Von Martius percorreu diversas regiões brasileiras a cavalo, durante três anos, até se hospedar na fazenda do Soberbo. Conhecedor de mais de 12 mil espécies da fauna e da flora brasileiras, Von Martius fez um trabalho tão significativo que o Dia Nacional da Botânica, 17 de abril, é comemorado na data de seu nascimento. (Fonte: http://mapadecultura.rj.gov.br/guapimirim/museu-von-martius/)
} 
segundo eles, por um "grupo de chineses" que ali planejava construir um restaurante. Os representantes da Associação de Moradores alegavam que a casa já estava bastante deteriorada e solicitavam nosso auxílio, uma vez que haviam visto tratar-se de uma equipe de uma universidade pública federal. Tive a ideia de realizar uma filmagem entrevistando os ocupantes da casa, com o intuito de averiguar a situação. Evidentemente, que esta era uma atitude pouco ortodoxa da minha parte, talvez indo além dos objetivos da pesquisa propriamente dita. Mas, entendi que podia colaborar de algum modo num "desejo de preservação de memória" de uma Associação de Moradores que se ressentia de interlocução por parte do poder público local. A ação foi produtiva. Os "chineses" nos receberam muito desconfiados. Dissemos que estávamos realizando uma pesquisa sobre a memória daquela região e que tínhamos sabido que a casa havia pertencido ao pintor Henrique Bernardelli. Sabíamos que ali havia um painel relacionado a uma de suas pinturas e gostaríamos de vê-lo. Os "chineses" nos deixaram entrar, nos mostraram a parede, onde a pintura estava já bastante destruída, com rabiscos e pinturas superpostas. A casa estava numa situação também muito precária, com barracas armadas por todo lado, o que indicava uma situação de ocupação desordenada. De qualquer modo, os "ocupantes" foram gentis conosco e responderam a nossas perguntas, dizendo que estavam ali provisoriamente e que não tinha intenção em permanecer por muito tempo, que desconheciam quem havia sido o antigo dono da casa e a história da região. Agradecemos e partimos. Algumas semanas depois, recebemos um telefonema da Associação, nos agradecendo, dizendo que graças a nossa intervenção, o Prefeito havia tomado a decisão de transformar a casa num centro cultural que servisse à comunidade e preservasse a memória de Henrique Bernardelli. De algum modo, pudemos contribuir para um projeto sobre a memória e a cultura locais.

Link do projeto museus do rio:

$\underline{\text { www.museusdorio.com.br }}$

\section{Para futuros desdobramentos}

Procurei tratar do "imprevisível", aspecto sempre presente em pesquisas antropológicas. O que eu gostaria de chamar a atenção aqui é que mais do que tentar "controlar" estas situações, o que é uma das vias para se lidar com o "imprevisível", 
procuramos perceber seu caráter expressivo. O "imprevisível" fala algo e é isso que devemos tentar perceber. Com o registro audiovisual, estas falas ficam ainda mais explícitas. Muitas vezes, só nos damos conta quando vemos posteriormente o material filmado. Assim como Clifford Geertz ${ }^{20}$, no magistral artigo sobre a briga de galos, fez uma série de inferências sobre as "piscadelas" que ele observava no contexto pesquisado, penso que o "imprevisível" numa pesquisa é pleno de significados. Procurei mostrar também casos em que o "imprevisível" estava diretamente associado ao registro audiovisual, à câmera, à filmagem, às representações sobre o que é uma filmagem, para que serve uma filmagem, o que se espera conseguir com um filme e assim por diante.

O audiovisual, portanto, não é apenas uma ferramenta de trabalho, seu uso produz um sentido singular, específico, que diz respeito a uma linguagem associada a muitas noções num mundo midiatizado. Quais as fantasias, as aspirações, os projetos que sucitam uma câmera em movimento? $\mathrm{O}$ ato da filmagem e a produção de um filme podem também ser percebidos como "disparadores" desencadeando emoções, pensamentos, sentimentos e gerando performances. A relação entre pesquisador e pesquisado é muito mais complexa que podemos supor. Cada pesquisa apresenta suas próprias surpresas e os acontecimentos mais imprevistos. Mas isto não é ruim, pelo contrário, pode trazer maior dinamismo e riqueza à aventura da pesquisa e do registro audiovisual. O importante é aprender com estas experiências.

\section{Referências}

ABREU, Regina. "Daime Santa Maria: Uma Antropologia de Audios e Imagens". In: Comunicações do Iser, v.10, n.1. Rio de Janeiro: ISER, 1984. p. 36-46.

Plantas Psicoativas: Símbolos de Identidade Social. In: Odair Dias Gonçalves; Francisco Inácio Bastos. (Org.). Só Socialmente. 1ed. Rio de Janeiro: Relume Dumará, 1992, v. 1, p. 5-30.

. "Eterno Kuarup, patrimônio cultural xinguano". In: LOPES, Antonio Herculano (Org.) Religião e Performance ou As Performances das Religiões Brasileiras, v.1, cap. 10. Rio de Janeiro: Contra-capa, 2007. p. 185-195.

BARTHES, Roland. O grau zero da escrita. São Paulo: Martins Fontes, 2004b.

BENJAMIN, Walter. Sobre arte, técnica, linguagem e política. Lisboa: Relógio d'Água, 1992.

CERTEAU, Michel de. A escrita da História. Rio de Janeiro: Forense Universitária, 2007.

CLIFFORD, James. A Experiência Etnográfica. Antropologia e Literatura no século $X X$. Rio de Janeiro: UFRJ, 1998.

${ }^{20}$ GEERTZ, Clifford. A Interpretação das Culturas. Rio de Janeiro: Ed. LTD, 1989. 
DELEUZE, Gilles. "Sobre Spinoza". In: Cours Vincennes, 1978. Disponível em: http://www.webdeleuze.com/php/texte.php?cle=194\&groupe=Spinoza\&langue=5.

DEVOS, Rafael. "Quando a câmera "vira personagem": ponto de vista em movimentos na busca de imagens do outro em documentários etnográficos". In: Iluminuras, v.2, n.3. Porto Alegre: BIEV/ UFRGS, 2001. Disponível em: http://seer.ufrgs.br/iluminuras/issue/view/768 .

FOUCAULT, Michel. O que é um autor? Lisboa: Vega, 1992. . A ordem do discurso. Lisboa: Relógio d'Água, 1997.

GEERTZ, Clifford. A Interpretação das Culturas. Rio de Janeiro: Ed. LTD, 1989.

ROCHA, Ana Luiza Carvalho da; ECKERT, Cornelia. "Imagem recolocada: pensar a imagem como instrumento de pesquisa e análise do pensamento coletivo". In: Iluminuras, v.2, n.3. Porto Alegre: BIEV/ UFRGS, 2001. Disponível em: http://seer.ufrgs.br/iluminuras/issue/view/768 .

VELHO, Gilberto. Nobres e Anjos. Um Estudo de Tóxicos e Hierarquia. Rio de Janeiro: Fundação Getúlio Vargas, 1988.

Recebido em: 20/04/2012

Aprovado em: 17/09/2012 